\title{
Perceived Sources and Coping Mechanisms of Stress among Undergraduate Dental Students in Aden University
}

\author{
Liza Alhamadi ${ }^{1}$, Ahmed Mohamed ${ }^{2}$, Ashraf Wahdan ${ }^{3}$, Ahlam Hibatulla ${ }^{4}$ \\ ${ }^{1}$ BDS, MS in Dental Public Health, Alexandria University, Egypt \\ Lizahammadi[at]gmail.com \\ ${ }^{2}$ Pediatric Dentistry and Dental Public Health Department, Alexandria University, Egypt \\ ${ }^{3}$ Biostatistics Department, High Institute of Public Health, Alexandria University, Egypt \\ ${ }^{4}$ Department of Orthodontics, Aden University, Yemen
}

\begin{abstract}
In Aden, there is no study focused on stressors among dental students. This study was conducted aiming to determine the perceived sources of stress, and reporting the coping mechanisms used by undergraduate dental student in Aden University. The cross-sectional design was carried out during fall 2014 academic semester, using a self administered questionnaire among second to fifth year bachelor students of dental faculty (Aden - Yemen). It showed a response rate of 78.16\%. Stressors related to "faculty relations" topped the other stress areas, with overall mean percentage of (68.1\%) for moderate or severe stress. Followed by clinical factors stressors (66.0\%) and academic performance stressors (62.6\%). The first ranked stressors were difficulties to get suitable patient (95.6\%), inadequate resources available in the clinic (87.8\%) and your expectation of dental college are not very much like what you imagined them to be (85.7\%). The leading stress reduction technique among the studied students was praying or spiritual activity. This study concluded that dental students in Aden University are in need for support and guidance and there is a need to shift towards a more student-centered curriculum.
\end{abstract}

Keywords: Stress, Cope, Aden, Dental, Students

\section{Introduction}

Dental school is perceived to be stressful as it is known to be highly demanding and intellectually challenging. ${ }^{(1)}$ Dental students not only face the stressors that dental practitioners face, but also ones that are specific to a student. It has been found that dental students have stress levels higher than in the general population. ${ }^{(2,3)}$

Stress in dental school has been significantly linked to student symptoms of anxiety, depression and hostility. As well, students who are stressed or are suffering from burnout are at a higher risk of suicidal thoughts, alcohol and drug abuse, and impulsive sexual activity. ${ }^{(3-5)}$

The dental college in Aden city, Republic of Yemen, founded 17 years ago, only for undergraduate studies, with a load of approximately 150 students per year from Aden and the nearby governorates. These students are facing different political, social, economic and cultural stressors that affect their academic performance. Till now, there is no study focus on those stressors in dental students in Aden. This study was conducted aiming to determine the perceived sources of stress, and reporting the coping mechanisms used by undergraduate dental student in Aden University.

\section{Literature Survey}

Stress and dental professionals

Although dentists tend to enjoy better physical health, it has been shown that their mental health is poorer than the general public. ${ }^{(6)}$ Studies reporting levels of distress and emotional exhaustion of dentists found between 19 to $38 \%$ of those surveyed always feel anxious or distressed. ${ }^{(7,8)}$

Many studies have been conducted to address the stress of dental students. Due to the differences in social-cultural background, and personal beliefs and attitudes, students in different countries perceive stressors in their dental environments differently. ${ }^{(9)}$

Dental students need to obtain training in both theoretical and surgical aspects of dental care, including performing treatments on patients to qualify as competent dental professionals. In the preclinical years, dental students need to manage laboratory requirements that require a significant amount of time and manual skills. The clinical part of their training requires that students be responsible for their patients' care and perform irreversible dental treatments on those patients. All these factors collectively contribute to significant amounts of stress for dental students that make them at additional risk for psychiatric problems compared to other university students. ${ }^{(10,11)}$ 


\section{International Journal of Science and Research (IJSR) \\ ISSN (Online): 2319-7064 \\ Index Copernicus Value (2013): 6.14 | Impact Factor (2014): 5.611}

Stress levels rise in line with higher levels of educational attainment. It was noted that psychological distress in firstyear medical undergraduates was predictive of occupational stress in later years. ${ }^{(12,13)}$

Dental students were observed to have similar emotional distress to patients received psychiatric attention. ${ }^{(14)}$ Heath et al (1999) $)^{(15)}$ also reported that stressful events experienced during undergraduate training may have some influence on the future profession. Identification and clearer understanding of potential stressors in the dental environment in the early years of training and their impact on students will help students and faculty to find appropriate approaches in handling students' stress. ${ }^{(16,17)}$

\section{Stress and cope}

Once the stressor has been appraised, coping then occurs by deciding which behaviors should be utilized to handle the event. Coping is defined as the effort to manage stress by attempting to reduce the perceived discrepancy between situation demands and personal resources. ${ }^{(18)}$

Research on coping has found support for the categorization of coping into approach and avoidant strategies. ${ }^{(18)}$ Approach strategies are defined as direct efforts to change a stressful event. It includes supportseeking, understanding and acceptance and problem solving. ${ }^{19,20)}$ Avoidant strategies are defined as the absence of attempts to change the situation. It includes wishful thinking, avoiding problem, and denying that a problem exists. ${ }^{(19,20)}$

Generally, persons who actively coped with certain kinds of life events were more likely to have better mental health and immune function. ${ }^{(21-24)}$ In contrast, those who adopted avoidance coping such as denial and disengagement, generally had increased distress and poorer mental health. ${ }^{(25)}$

\section{Methods}

A cross-sectional design was carried out during fall 2014 academic semester, using a self administered questionnaire (modified version of the Dental Environment Stress questionnaire) among second to fifth year bachelor students of dental faculty at University of Aden - Republic of Yemen. The close-ended questioner was divided into 4 sections:

1)Section A consists of questions about characteristics of the participants (gender, age, nationality, residence and the study year).

2)Section B identified potential stressors among student addressing 4 stressor domains (personal life issue, academic performance, faculty relation, and clinical responsibility).

3) Section C identified physical and behavioral consequence of stress.

4)Section D about what students did to relieve stress.
Questionnaires were presented in English plus Arabic languages. The participants assessed the stressors on a 4points Likert scale ranked as not stressful, slightly stressful, moderately stressful and severely stressful. Categories of moderately stressful and severely stressful were combined to obtain the overall percentage of the students who felt certain factors were stressful.

After data collection and entry into computer software, the reliability test showed a Cronbach's alpha of 0.87 .

\section{Ethical Considerations}

The consent of the faculty's Research Ethics Committee in the Faculty of Dentistry Alexandria University was first secured. The questionnaire was anonymous to gain participants trust and encourage them to share sensitive information about their sources of stress.

Confidentiality of obtained data through questionnaires was ensured. Returning a filled questionnaire was considered indicative of implicit consent with no need for singing a written consent form since there is minimal risk related to answering the anonymous questionnaire.

\section{Results \& Discussion}

The current study is the first survey concerning stress among dental students in the dental faculty of Aden University in Yemen. This may help in better understanding of the situation in this dental school which is located in an area exposed to different social, political and financial stressors in the different daily life aspects.

The total number of students registered in Dental Faculty of Aden University during the academic year 2014-2015 were 403 students studying from the 2nd to the 5th academic years. The total number of students who responded to the questionnaire of this study was 315 students, representing a response rate of $78.16 \%$. This rate may be attributed to the deteriorated general situation of Aden city at the time of the study.

The demographic characteristics of the responding dental students according to their academic years were reported in table 1 . Slightly higher females responded than males and most of them were single students. 


\section{International Journal of Science and Research (IJSR) \\ ISSN (Online): 2319-7064}

Index Copernicus Value (2013): 6.14 | Impact Factor (2014): 5.611

\begin{tabular}{|c|c|c|c|c|c|c|c|c|c|c|}
\hline \multirow{3}{*}{ Item } & \multicolumn{8}{|c|}{ Academic year } & \multirow{2}{*}{\multicolumn{2}{|c|}{$\begin{array}{c}\text { Total } \\
(\mathrm{n}=315)\end{array}$}} \\
\hline & \multicolumn{2}{|c|}{$2^{\text {nd }}(n=48)$} & \multicolumn{2}{|c|}{$3^{\text {rd }}(n=62)$} & \multicolumn{2}{|c|}{$4^{\text {th }}(n=70)$} & \multicolumn{2}{|c|}{$\mathbf{5}^{\text {th }}(\mathrm{n}=135)$} & & \\
\hline & № & $\%$ & № & $\%$ & № & $\%$ & № & $\%$ & № & $\%$ \\
\hline \multicolumn{11}{|l|}{ Gender: } \\
\hline Male & 12 & 25.0 & 28 & $\begin{array}{c}45 . \\
2\end{array}$ & 51 & $\begin{array}{c}72 . \\
9\end{array}$ & 48 & $\begin{array}{c}35 . \\
6\end{array}$ & 139 & $\begin{array}{c}44 . \\
1\end{array}$ \\
\hline Female & 36 & 75.0 & 34 & $\begin{array}{c}54 . \\
8 \\
\end{array}$ & 19 & $\begin{array}{c}27 . \\
1 \\
\end{array}$ & 87 & $\begin{array}{c}64 . \\
4 \\
\end{array}$ & 176 & $\begin{array}{c}55 . \\
9 \\
\end{array}$ \\
\hline \multicolumn{11}{|c|}{ Age (years): } \\
\hline $20-21$ & 44 & 91.7 & 5 & 8.1 & - & - & - & - & 49 & $\begin{array}{c}15 . \\
6\end{array}$ \\
\hline $22-23$ & 4 & 8.3 & 33 & $\begin{array}{c}53 . \\
2\end{array}$ & 13 & $\begin{array}{c}18 . \\
6\end{array}$ & 6 & 4.4 & 56 & $\begin{array}{c}17 . \\
8\end{array}$ \\
\hline $24-25$ & - & - & 24 & $\begin{array}{c}38 . \\
7\end{array}$ & 51 & $\begin{array}{c}72 . \\
9\end{array}$ & 91 & $\begin{array}{c}67 . \\
4\end{array}$ & 166 & $\begin{array}{c}52 . \\
7\end{array}$ \\
\hline $26-27$ & - & - & - & - & 6 & 8.6 & 38 & $\begin{array}{c}28 . \\
1 \\
\end{array}$ & 44 & $\begin{array}{c}14 . \\
0\end{array}$ \\
\hline \multicolumn{11}{|c|}{ Marital status: } \\
\hline Single & 48 & 100 & 57 & $\begin{array}{c}91 . \\
9\end{array}$ & 62 & $\begin{array}{c}88 . \\
6\end{array}$ & 97 & $\begin{array}{c}71 . \\
9\end{array}$ & 264 & $\begin{array}{c}83 . \\
8\end{array}$ \\
\hline Married & - & - & 5 & 8.1 & 8 & $\begin{array}{c}11 . \\
4\end{array}$ & 38 & $\begin{array}{c}28 \\
1\end{array}$ & 51 & $\begin{array}{c}16 . \\
2\end{array}$ \\
\hline
\end{tabular}

In general, stressors related to "faculty relations" topped the other stress areas, with overall mean percentage of (68.1\%) of students reporting to be moderately or severely stressed by them. This was followed by "clinical factors stressors" with a mean percentage of $(66.0 \%)$. This is considered higher than that reported in the previous study of five European dental schools, ${ }^{(10)}$ but near to that reported among Saudi dental students in the clinical academic years. ${ }^{(26)}$

Academic performance stressors came third in order, with a mean percentage of (62.6\%) [table 2]. These findings are similar to that reported in several previous studies, ${ }^{(10,27-29)}$ where elements related to academic performance stressors appeared more stressful for undergraduate dental students.

Table (2): Percentages of students reporting different stress levels according to he various stress areas

\begin{tabular}{|c|c|c|}
\hline Stress areas & $\begin{array}{c}\text { Not or slightly } \\
\text { stressed }\end{array}$ & $\begin{array}{c}\text { Moderately } \\
\text { or severely } \\
\text { stressed }\end{array}$ \\
\hline $\begin{array}{c}\text { Mean percentage of students with different } \\
\text { levels of stress due to life issues stressors }\end{array}$ & $73.2 \%$ & $26.8 \%$ \\
\hline $\begin{array}{c}\text { Mean percentage of students with different } \\
\text { levels of stress due to personal factors } \\
\text { stressors }\end{array}$ & $55.6 \%$ & $44.4 \%$ \\
\hline $\begin{array}{c}\text { Meanpercentage of students with different } \\
\text { levels of stress due to academic } \\
\text { performance stressors }\end{array}$ & $37.4 \%$ & $62.6 \%$ \\
\hline $\begin{array}{c}\text { Meanpercentage of students with different } \\
\text { levels of stress due to faculty relation } \\
\text { stressors }\end{array}$ & $31.9 \%$ & $68.1 \%$ \\
\hline $\begin{array}{c}\text { Meanpercentage of students with different } \\
\text { levels of stress due to clinical factors } \\
\text { stressors }\end{array}$ & $34.0 \%$ & $66.0 \%$ \\
\hline
\end{tabular}

Figure 1 depicted the ten ranked stress items reported to be moderately or severely stressful by the studied students. It was found that the first two stress items most frequently reported to produce moderate or severe stress were related to the stress area "clinical factors" namely; "difficulties to get suitable patient (95.6\%)" and "inadequate resources available in the clinic (87.8\%)". This finding is in agreement with that reported by a study conducted among Saudi clinical dental students, where $71.6 \%$ were stressed due to difficulties to get suitable patient. ${ }^{(26)}$

The third common stressor was "your expectation of dental college are not very much like what you imagined them to be (85.7\%)" which is belonging to "personal factors" stressors. This finding is not far from that reported by Preoteasa et al, ${ }^{(30)}$ in their study among Romanian dental students as well as among Australian Dental students. ${ }^{(31)}$ It may be attributed to that dental students experience feeling overwhelmed by the information load with the inability to manage the time, coupled with workload and unrealistic expectation and/or confidence in one's own ability to fulfill all the requirements.

The fourth and fifth common stressors belong to "academic performance" were "examination and grade (81.9\%)" and "having a lecture, clinical or laboratory session immediately before an exam on its scheduled day (79.4\%)". These findings are similar to that reported in several previous studies, ${ }^{(10,27-29)}$ where examinations and grades appear to be the most stressful elements for undergraduate dental students, along with limited time for relaxation or outside activities.

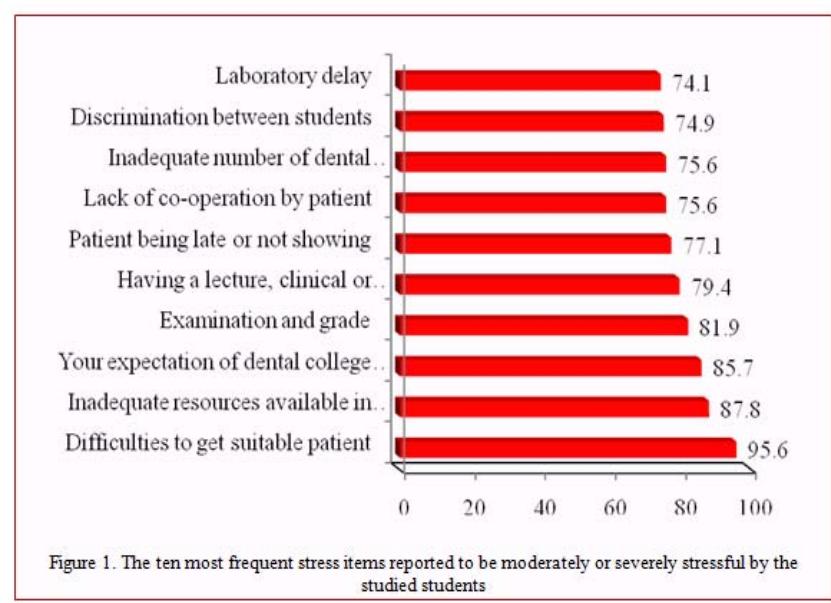

The leading stress reduction technique among the studied dental students in Aden University was praying or spiritual activity, followed by watching movies, communication with friends and family support [table 3]. The studied students were all Muslims, and in Yemen the society is more in contact with religious matters. Because of that, higher percentages of the studied males and females reported praying or spiritual activity as the first stress reduction technique they use. Praying or performing spiritual activities was also reported among other Islamic society such as among Malaysian dental students, ${ }^{(32)}$ as a popular stress reduction technique. It is believed that praying or performing spiritual activities provide calmness and hope for a better life. ${ }^{(33)}$

A recent study for stress conducted among Yemeni dentists showed that in Yemeni community as a religious society, stressed dentists prefer to deal with stress by praying, reading the Quran, and sharing problems with family and friends. ${ }^{(34)}$

In comparing between male and female coping mechanisms; male students cope with "physical activity", "watching movies at home or at the cinema" and "talking with lecturers or mentors or academic advisors", more than female students. While female students cope with "communication with friends", "family support" and "shopping", more than male students. These activities were also commonly adopted methods of stress reduction among Nepali dental students. ${ }^{(35)}$ The study among Canadian dental students, ${ }^{(29)}$ found students who received more social support tended to have less stress; such social support can come from teachers, parents or other students. 


\section{International Journal of Science and Research (IJSR) \\ ISSN (Online): 2319-7064}

Index Copernicus Value (2013): 6.14 | Impact Factor (2014): 5.611

Cigarettes smoking and Khat chewing were coping mechanism for male students and only few percentages of females used these coping mechanisms [table 3]. This is similar to the study reported among Saudi dental students, ${ }^{(36)}$ which concluded that the lower smoking rates among female dental students could reflect the fact that smoking by females is culturally unacceptable, especially in conservative societies like Saudi Arabia.

Khat (Catha Edulis) leaves, which are known to contain psycho-active ingredients, cathinone, are commonly chewed in Yemen. It is known to induce a state of euphoria and elation with feelings of increased alertness and arousal. $^{(37,38)}$

Table (3): Coping mechanisms toward stress among the students being moderately or severely stressed in regard to gender and academic year

\begin{tabular}{|l|c|c|c|c|c|c|}
\hline \multirow{2}{*}{ Coping mechanisms } & \multicolumn{2}{|c|}{ Male (n=139) } & \multicolumn{2}{c|}{ Female (n=176) } & \multicolumn{2}{|c|}{$\begin{array}{c}\text { Total } \\
(\mathrm{n}=315)\end{array}$} \\
\cline { 2 - 7 } & $№$ & $\%$ & № & $\%$ & № & $\%$ \\
\hline Praying/spiritual activity & 132 & 95.0 & 149 & 84.7 & 281 & 89.2 \\
\hline Communication with friends & 91 & 65.5 & 140 & 79.5 & 231 & 73.3 \\
\hline $\begin{array}{l}\text { Watchingmovies at home or at the } \\
\text { cinema }\end{array}$ & 111 & 79.9 & 117 & 66.5 & 228 & 72.4 \\
\hline Family support & 90 & 64.7 & 132 & 75.0 & 222 & 70.5 \\
\hline Physical activity & 97 & 69.8 & 114 & 64.8 & 211 & 67.0 \\
\hline Meditation & 95 & 68.3 & 109 & 61.9 & 204 & 64.8 \\
\hline $\begin{array}{l}\text { Listening to music/playing a musical } \\
\text { instrument }\end{array}$ & 80 & 57.6 & 103 & 58.5 & 183 & 58.1 \\
\hline Shopping & 72 & 51.8 & 106 & 60.2 & 178 & 56.5 \\
\hline $\begin{array}{l}\text { Talking with lecturers/ } \\
\text { mentors/academic advisors }\end{array}$ & 84 & 60.4 & 42 & 23.9 & 126 & 40.0 \\
\hline Readmagazines or books & 54 & 38.8 & 60 & 34.1 & 114 & 36.2 \\
\hline $\begin{array}{l}\text { Professional help: doctor, } \\
\text { psychiatrist, counselor }\end{array}$ & 53 & 38.1 & 49 & 27.8 & 102 & 32.4 \\
\hline Chewing Khat & 28 & 20.1 & 6 & 3.4 & 34 & 10.8 \\
\hline Smoking cigarettes & 23 & 16.5 & 3 & 1.7 & 26 & 8.3 \\
\hline Going to sea & 3 & 2.2 & 4 & 2.3 & 7 & 2.2 \\
\hline
\end{tabular}

\section{Conclusion \& Recommendation}

The study concluded that dental students in Aden University are in need for support and guidance especially those with severe stress and recommended to reconsider the existing educational system with a shift towards a more student-centered curriculum, with increasing the number of training settings and clinical facilities and decreasing the number of the newly admitted students to the Dental Faculty.

\section{References}

[1] Piazza-Waggoner CA, Cohen LL, Kohli K, Taylor BK. Stress management for dental students performing their first pediatric restorative procedure. J Dent Educ 2003; 67(5): 542-8.

[2] Newbury-Birch D, Lowry RJ, Kamali F. The changing patterns of drinking, illicit drug use, stress, anxiety and depression in dental students in a UK dental school: a longitudinal study. Br Dent J 2002; 192(11): 646-9.

[3] Plasschaert AJ, Hoogstraten J, van Emmerik BJ, Webster DB, Clayton RR. Substance use among Dutch dental students. Community Dent Oral Epidemiol 2001; 29(1): 48-54.
[4] Beiter R, Nash R, McCrady M, Rhoades D, Linscomb M, Clarahan $\mathrm{M}$, et al. The prevalence and correlates of depression, anxiety, and stress in a sample of college students. J Affect Disord 2015; 173: 90-6.

[5] Makhal M, Ray PK, Ray Bhattacharya S, Ghosh S, Majumder U, De S, et al. Prevalence of Psychiatric Morbidity Among Undergraduate Students of a Dental College in West Bengal. J Clin Diagn Res 2015; 9(7): Zc68-71.

[6] Alexander RE. Stress-related suicide by dentists and other health care workers. Fact or folklore? J Am Dent Assoc 2001; 132(6): 786-94.

[7] Baldwin PJ DM, Rennie JS. Young dentists--work, wealth, health and happiness. Br Dent J 1999; 186(1): 30-6.

[8] Newbury-Birch D LR, Kamali F. The changing patterns of drinking, illicit drug use, stress, anxiety and depression in dental students in a UK dental school: a longitudinal study. Br Dent J 2002; 192(11): 646-9.

[9] Vivian AG. Stress and salivary biomarkers among dental undergraduates - a longitudinal study [M.Sc. Thesis]: Dept. of Community OFM, Yong Loo Lin School of Medicine, National University of Singapore; 2006.

[10] Gorter R FR, Hammen S, Murtomaa H, Blinkhorn A, Humphris G. Psychological stress and health in undergraduate dental students: fifth year outcomes compared with first year baseline results from five European dental schools. Eur J Dent Educ 2008; 12(2): 61-8.

[11]Elani HW. Stress in Dental Students: A Mixed Methods Study [PhD Thesis]: Faculty of Dentistry. McGill University MAfhdlmc.

[12] Rada RE J-LCS, burnout, anxiety and depression among dentists. J Am Dent Assoc 2004; 135(6): 788-94.

[13] Guthrie E BD, Bagalkote H, Shaw C, Campbell M, Creed F. Psychological stress and burnout in medical students: a five-year prospective longitudinal study. J R Soc Med 1998; 91(5): 237-43.

[14] Makhal M RP, Ray Bhattacharya S, Ghosh S, Majumder U, De S, et al. Prevalence of Psychiatric Morbidity Among Undergraduate Students of a Dental College in West Bengal. J Clin Diagn Res 2015; 9(7): Zc68-71.

[15] Heath JR MT, Umar MS. Perceived sources of stress in dental students. Dent Update 1999; 26(3): 94-8, 100.

[16] Humphris G BA, Freeman R, Gorter R, Hoad-Reddick G, Murtomaa $\mathrm{H}$, et al. Psychological stress in undergraduate dental students: baseline results from seven European dental schools. Eur J Dent Educ 2002; 6(1): 22-9.

[17] Westerman GH GT, Lupo JV, Mitchell RE. Relationship of stress and performance among first-year dental students. J Dent Educ 1986; 50(5): 264-7.

[18] Lazarus RS. Stress and Emotion: A New Synthesis. New York: Springer Publishing Company; 1999. 360 p.

[19] Pakenham KI CJ, Bursnall S, Cannon T. Relations between social support, appraisal and coping and both positive and negative outcomes in young carers. $\mathrm{J}$ Health Psychol 2007; 12(1): 89-102.

[20]Chiriboga DA, Bailey J. Stress and burnout among critical care and medical surgical nurses: a comparative study. Ccq 1986; 9(3): 84-92. 


\section{International Journal of Science and Research (IJSR) \\ ISSN (Online): 2319-7064}

Index Copernicus Value (2013): 6.14 | Impact Factor (2014): 5.611

[21]Billings AG, Moos RH. The role of coping responses and social resources in attenuating the stress of life events. J Behav Med 1981; 4(2): 139-57.

[22] Esterling BA AM, Kumar M, Schneiderman N. Defensiveness, trait anxiety, and Epstein-Barr viral capsid antigen antibody titers in healthy college students. Health Psychol 1993; 12(2): 132-9.

[23] Goodkin K FI, Feaster D, Leeka J, Rishel DD. Life stressors and coping style are associated with immune measures in HIV-1 infection--a preliminary report. Int J Psychiatry Med 1992; 22(2): 155-72.

[24] Molassiotis A VDAO, Milligan DW, Goldman JM. Symptom distress, coping style and biological variables as predictors of survival after bone marrow transplantation. J Psychosom Res 1997; 42(3): 275-85.

[25] Carver CS PC, Harris SD, Noriega V, Scheier MF, Robinson DS, et al. How coping mediates the effect of optimism on distress: a study of women with early stage breast cancer. J Pers Soc Psychol 1993; 65(2): 375-90.

[26] Al-Samadani KH, Al-Dharrab A. The Perception of Stress among Clinical Dental Students. World J Dent 2013; 4(1): 24-8.

[27] Morse Z, Dravo U. Stress levels of dental students at the Fiji School of Medicine. Eur J Dent Educ 2007; 11(2): 99-103.

[28] Alzahem AM, van der Molen HT, Alaujan AH, Schmidt HG, Zamakhshary MH. Stress amongst dental students: a systematic review. Eur J Dent Educ 2011; 15(1): 8-18.

[29] Muirhead V, Locker D. Canadian dental students' perceptions of stress and social support. Eur J Dent Educ 2008; 12(3): 144-8.

[30] Preoteasa CT, Mircescu G, Buzea MC, Preoteasa E. Sources of stress and well-being in dental students. Roman J Oral Rehab 2015; 7(1): 28-32.

[31] Sanders AE, Lushington K. Sources of stress for Australian dental students. J Dent Educ 1999; 63(9): 688-97.

[32] Ahmad MS, Md Yusoff MM, Abdul Razak I. Stress and its relief among undergraduate dental students in Malaysia. Southeast Asian J Trop Med Public Health 2011; 42(4): 996-1004.

[33] Bormann JE, Smith TL, Becker S, Gershwin M, Pada L, Grudzinski AH, et al. Efficacy of frequent mantram repetition on stress, quality of life, and spiritual wellbeing in veterans: a pilot study. J Holist Nurs 2005; 23(4): 395-414.

[34] Al-Zubair NM, Al-ak'hali MS, Ghandour IA. Stress among dentists in Yemen. Saudi J Den Research 2015; 6: 140-5.

[35] Paudel S, Subedi N, Shrestha A. Stress and its relief among undergraduate dental students in a tertiary health care centre in eastern Nepal. Dentistry 2013; 3(2): $1-5$.

[36] AlSwuailem AS, AlShehri MK, Al-Sadhan S. Smoking among dental students at King Saud University: Consumption patterns and risk factors. Saudi Dent J 2014; 26(3): 88-95.

[37] Nencini P, Ahmed AM. Khat consumption: a pharmacological review. Drug Alcohol Depend 1989; 23(1): 19-29.
[38] Dhaifalah I, Santavy J. Khat habit and its health effect. A natural amphetamine. Biomed Pap Med Fac Univ Palacky Olomouc Czech Repub 2004; 148(1): 11-5.

\section{Author Profile}

Liza Ahmed Alhamadi received the B.D.S. in Dental and Oral Surgery from Aden University, Faculty of Dentistry 2007. During 2006 till the start of postgraduate study, she practiced in different areas of Yemen. She started preparation of master degree in Pediatric Dentistry and Dental Public Health at Faculty of Dentistry, Alexandria University since 2012. 